Golden Gate University School of Law GGU Law Digital Commons

2010

Transformative Constitutionalism in South Africa: Creative Uses of Constitutional Court Authority to Advance Substantive Justice

Eric Christiansen

Golden Gate University School of Law, echristiansen@ggu.edu

Follow this and additional works at: http://digitalcommons.law.ggu.edu/pubs

Part of the Comparative and Foreign Law Commons, and the Constitutional Law Commons

Recommended Citation

13 J. of Gender, Race \& Justice 575 (2010)

This Article is brought to you for free and open access by the Faculty Scholarship at GGU Law Digital Commons. It has been accepted for inclusion in Publications by an authorized administrator of GGU Law Digital Commons. For more information, please contact jischer@ggu.edu. 


\title{
Transformative Constitutionalism in South Africa: Creative Uses of Constitutional Court Authority to Advance Substantive Justice
}

\author{
Eric C. Christiansen*
}

\section{INTRODUCTION}

Substantive justice is an ever-elusive goal for constitution-makers. A desire to structure a system of government and draft rights protections that will advance genuine justice for their people is almost always an aspiration claimed by nation-builders. But it is a goal that is typically met imperfectly, if not inadequately. Nevertheless, seeking justice that is superior to that of the previous regime motivates many countries to reformulate their government or change their laws, or even to amend or rewrite their constitutions. And any such quest for justice is made much more challenging if the country aspires to actualize substantive justice: justice in its fuller dimensions as demonstrated by more than formal, legal equality or the exclusive protection of negative liberties. ${ }^{1}$

For political theorists, workaday advocates, and legal academics who seek justice in this richer sense, studying South Africa is a natural area of inquiry. Since the end of apartheid in the early 1990s, the Republic of South Africa has attempted an intentional process of remaking itself as a "human

\footnotetext{
* Professor of Law and Associate Dean for Faculty Scholarship, Golden Gate University School of Law, San Francisco, California; J.D., New York University School of Law, 2001; M.A., University of Chicago, 1995. This Article is an expanded version of my presentation at the Conference on Conceptualizing Substantive Justice held at University of Denver Sturm College of Law in April 2009; my thanks to the organizer Nancy Ehrenreich and the many participants. In writing this Article, I also benefited from helpful comments from my colleagues, Professors Chester Chuang, Michele Benedetto Neitz, and Rachel Van Cleave, and received very valuable aid from my research assistants Erik Knuppel and Vanessa Sundin. Of note, this Article's reflections upon and assertions regarding the South African Constitutional Court are drawn in part from my personal experience working in South Africa as a foreign law clerk to the former Chief Justice of South Africa, Arthur Chaskalson. The opinions expressed herein (and any errors) are the author's own.

1. My use of the term "negative liberties" here (and later) refers to the traditional civil and political rights conceived of specifically (and for my purposes, merely) as an individual's right to be free from government interference. This is a distinction made in U.S. constitutional law most notably in DeShaney v. Winnebago County Dep't of Soc. Servs., 489 U.S. 189, 203-04 (1989) (Brennan, J., dissenting). See also, Bowers v. DeVito, 686 F.2d 616, 618 (7th Cir. 1982) ("The Constitution is a charter of negative liberties; it tells the state to let people alone; it does not require the federal government or the state to provide services, even so elementary a service as maintaining law and order.").
} 
rights state." ${ }^{2}$ Indeed, South Africa is the most frequently discussed example of this form of transformative constitutionalism: a conscious attempt to create a nation that would espouse and accomplish substantive justice in its political and economic facets. South Africa's 1996 Constitution declared the new nation to be "a society based on democratic values, social justice and fundamental human rights ...." with the express mission to "[i]mprove the quality of life of all citizens and free the potential of each person." ${ }^{3}$ South Africa has been attempting to transform itself through a constitution that zealously protects traditional civil and political rights and addresses the more fundamental elements of justice as well. Indeed, South Africa has established a jurisprudence of expansive dignity and equality protections as well as the only relatively comprehensive, affirmative social rights jurisprudence of any nation ${ }^{4}$ - a reflection of the transformative values of the Constitution and the South African Constitutional Court's commitment to the nation's justice-oriented ideology.

In late 2009, the Constitutional Court went through a symbolic but significant change. The Court acquired its third Chief Justice and lost the last sitting members of the first generation of Constitutional Court justices, as those judges appointed by President Mandela in the months after South Africa's first democratic elections retired due to judicial term limits. ${ }^{5}$ This occasion provides many commentators an opportunity to evaluate the work of the Court's first fifteen years. ${ }^{6}$ The conclusion of many critics will inevitably be that, while the Court (like the South African government generally) has been responsible for significant social and political progress,

2. Makua wa Mutua, Hope and Despair For a New South Africa: The Limits of Rights Discourse, 10 HARV. HUM. RTS. J. 63, 65 (1997); see also, Nelson Mandela, Speech at the Signing of the Constitution (Dec. 10, 1996), available at http://www.anc.org.za/ancdocs/history/mandela/ 1996/sp961210.html ("Let us give practical recognition to the injustices of the past, by building a future based on equality and social justice.”).

3. S. AFR. CONST. 1996 (discussing the goals of the Constitution in the preamble).

4. See generally Eric. C. Christiansen, Adjudicating Non-Justiciable Rights: Socio-economic Rights and the South African Constitutional Court, 38 Colum. Hum. RTS. L. Rev. 321 (2007) (explaining the historical development of social welfare rights jurisprudence through the process of "differentiated incorporation"). Although they are not the direct focus of this article, social welfare rights are unquestionably an element of substantive justice.

5. Zuma Welcomes Four New Judges, Pretoria News (S. Afr.), Oct. 12, 2009, at 2, available at http://www.iol.co.za/index.php?set_id=1\&click_id=13\&art_id=vn20091012040423 967C691607. Newly appointed justices hold office for non-renewable terms of 12 years or until the judge attains the age of 70, except where an Act of Parliament extends a term. S. AFR. CONST. 1996, ch. 8, § 176(1) (as amended by Act No. 34 of 2001 s. 15).

6. The South African Constitutional Court was created under the Interim Constitution. S. AFr. (Interim) CONST. 1993, ch. 7, § 98(1); repealed and replaced by the S. AFr. CONST. 1996, ch. 8, $\S 176$. Following the appointment of the justices, the Court was formally opened by President Mandela on February 14, 1995. ConstitutionalCourt.org.za, History of the Court of South Africa, http://www.constitutionalcourt.org.za/site/thecourt/history.htm (last visited Apr. 7, 2010). 
it has had only modest impact on the seemingly intractable problems of socio-economic injustice and substantive inequality.

However, for those critics - and I include myself among themparticularly interested in the Constitutional Court's ability to advance substantive justice, recent cases indicate the Court may be adding a new dimension to its experiment in transformative constitutionalism. In three relatively new judgments, the Court appears to be more creatively using certain elements of its institutional authority to promote genuine justice. If this assessment is correct, this would be another praiseworthy contribution of the South African Constitutional Court to the field of comparative constitutionalism and an additional way to promote its transformative agenda.

South Africa has already demonstrated the justiciability of enumerated social welfare rights and that the South African model of social welfare adjudication-one critical element of substantive justice-could be borrowed by other national courts. ${ }^{7}$ But these most recent developments, if they continue to be evidenced in future generations of the Court, are more easily exported to other nations because they do not require specific textual language (e.g., enumerated socio-economic rights) in the adopting nation's constitution. Rather, they demonstrate how purposive interpretation and creative application of a court's jurisdiction and remedial authority can advance justice. If this trend continues, it will highlight an additional opportunity for other nations to advance their own goals of genuine political and socio-economic justice.

In this Article, I will first discuss some easily overlooked constitutional tools for promoting greater social justice: the procedural provisions of the South African Constitution related to jurisdiction, access, remedies and constitutional interpretation. Following that, I will use three recent Constitutional Court cases to demonstrate the Court's creative (and promising) use of its judicial authority to advance substantive justice. By way of conclusion, I will elaborate on the meaning of these recent developments for the transformative agenda of South Africa and for other nations.

7. See generally Eric C. Christiansen, Exporting South Africa's Social Rights Jurisprudence, 5 LOY. U. CHI. INT'L L. REV. 29 (2007) (advocating the possibility of other countries adopting the South African model); Eric C. Christiansen, Using Constitutional Adjudication to Remedy SocioEconomic Injustice: Comparative Lessons from South Africa, 13 UCLA J. INT'L L. \& FoREIGN AFF. 369 (2008) (exploring South Africa's experience in using a constitution to enhance and protect social welfare). 


\section{THE PROCEDURAL AUTHORITY AND INTERPRETIVE MANDATE OF A TRANSFORMATIVE COURT}

Comparative constitutional law scholars look first to a constitution's rights provisions when they wish to assess the capacity of a constitution to advance justice. However, while this Article will discuss elements of the South African Bill of Rights, the initial focus is on a less likely set of provisions: the grant of jurisdiction to the courts, the provisions regarding access to courts for parties, the remedial powers of the South African judiciary, and the textual instructions related to the judicial tasks of statutory and constitutional interpretation. Understanding these provisions will help explain the expansive capacity of the South African Constitutional Court to advance substantive justice from a multitude of textual bases.

\section{A. The Constitutional Court in South Africa's Transition}

From the "talks about talks about talks" in 1989 to the effective date of the current constitution in 1997, the process of bringing constitutional democracy to South Africa was resolved through a negotiation process dominated by the generally opposed concerns of the ruling, white-minority National Party and the African National Congress. ${ }^{8}$ Despite imperfections in the drafting process and in the resulting document, the negotiations achieved a goal considered impossible for decades: a relatively peaceful shift from "racial autocracy to a non-racial democracy, by means of a negotiated transition, the progressive implementation of democracy, and respect for fundamental human rights."

The fundamental compromise that permitted agreement between the previously combative parties was a temporary governing arrangement to facilitate democratic elections and end apartheid. ${ }^{10}$ This agreement, the Interim Constitution, also contained a set of thirty-four mandatory principles (the aptly named, "Thirty-four Principles") that the negotiating parties agreed would govern the terms of the final Constitution to be drafted by a newly elected Constitutional Assembly. ${ }^{11}$ The Constitutional Court was

8. See generally Allister SPARKS, TOMORROW IS ANOTHER COUNTRY: THE INSIDE STORY of South Africa's Road to Change (1995); Patti Waldmeir, ANatomy of A Miracle: The END OF APARTHEID AND THE BIRTH OF THE NEW SOUTH AFRICA (1997) (both books providing general histories of the political transformation of South Africa at the end of the apartheid era).

9. Albie Sachs, Constitutional Developments in South Africa, 28 N.Y.U. J. INT’L L. \& POL. 695, 695 (1996).

10. Ex parte Chairperson of the Constitutional Assembly: In re Certification of the Constitution of the Republic of S. Afr. 1996 (4) SA 744 (CC) at ch. 1, para. 10-13 (S. Afr.) [hereinafter In re Certification of the Constitution].

11. S. AFr. (Interim) CONST. 1993, sched. 4. 
created by the Interim Constitution and was assigned the task of certifying that the final Constitution conformed to the negotiated agreement memorialized in the transitional document. ${ }^{12}$

The Thirty-four Principles established "the fundamental guidelines, the prescribed boundaries, according to which and within which the [Constitutional Assembly] was obliged to perform its drafting function."13 The final Constitution was not "certified" and hence not valid until the elected Constitutional Assembly could secure a Constitutional Court ruling to that effect. ${ }^{14}$ In fact, the first proposed draft was rejected on several grounds and had to be amended by the Constitutional Assembly in line with the Court's opinion. ${ }^{15}$ The amended text of the Constitution was approved by the Constitutional Court on December 4, 1996, and formally took effect on February 4, 1997. ${ }^{16}$ Hence, the Court played a decisive role in assuring the success of the negotiated transition to democracy, and it significantly influenced the final text of the Constitution.

The exceptional role played by the Court in the drafting process was not the only novel thing about the South African Constitutional Court. The Interim Constitution ended the era of parliamentary supremacy in South Africa and invested very broad judicial review authority in the courts of South Africa-including the power to review proposed legislation, national

\section{Id.}

13. In re Certification of the Constitution, supra note 10, at ch. 2, para. 32 .

14. See S. AFR. (Interim) CONST. 1993, ch. 5, § 71(2) ("The new constitutional text passed by the Constitutional Assembly, or any provision thereof, shall not be of any force and effect unless the Constitutional Court has certified that all the provisions of such text comply with the Constitutional Principles referred to in subsection (1)(a)."). "It is necessary to underscore again that the basic certification exercise involves measuring the [final constitutional text] against the [Thirty-four Principles]." In re Certification of the Constitution, supra note 10, at ch. 2, para. 32.

15. While acknowledging that the drafting marked a "monumental achievement" and that "in general and in the majority of its provisions" the Constitutional Assembly had succeeded, the Court stated "we ultimately come to the conclusion that the [proposed Constitution] cannot be certified because there are several respects in which there has been noncompliance" with the Thirty-four Principles. The Court returned the text to the Constitutional Assembly for revisions consistent with its ruling. Ex Parte Chairperson of the Constitutional Assembly: In re Certification of the Amended Text of the Constitution of the Republic of South Africa 1996, 1997 (2) SA 97 (CC) at para. 31 (S. Afr.) [hereinafter In re Certification of the Amended Text].

Justice Albie Sachs later identified this decision as a "unique jurisprudential and political event in the world," whereby the Constitutional Court declared the South African Constitution to be "unconstitutional." Albie Sachs, The Creation of South Africa's Constitution, 41 N.Y.L. SCH. L. REV. 669, 669 (1996).

16. In re Certification of the Amended Text, supra note 15, at para. 205 (S. Afr.). The amended text was completed on October 11, 1996, and approved by the Constitutional Court on December 4, 1996. Suzanne Daley, South African Constitution is Approved by High Court, N.Y. Times, Dec. 5, 1996, at A11. On December 10, 1996, the new Constitution was signed by President Mandela. Hugh Dellios, S. Africa Tries out New System with Risky Plan, CHI. TRIB., Dec. 11, 1996, at 1. It formally took effect on February 4, 1997. S. AFR. CONST. 1996. 
and provincial statutes, provincial constitutions, acts of the executive branch and administrative bodies, and decisions of lower courts on all matters related to the Constitution. ${ }^{17}$ For the most dramatic form of judicial review, invalidating laws passed by Parliament and the provincial assemblies, the Constitutional Court has a mandatory form of final review authority over all other courts. ${ }^{18}$

The inauguration of judicial review in 1993 was a significant change for South Africa. Apartheid in South Africa had been a parliamentary sovereignty system, vesting ultimate governmental authority in the national Parliament and not subjecting its laws to invalidation by the courts. ${ }^{19}$ Moreover, the onset of judicial review was not merely an experiment with a new constitutional model; judicial review played an essential role in facilitating the transformation from apartheid oppression to constitutional democracy.

A transition of the caliber and consequence of South Africa's could easily cripple a legal system. Doing away with all existing laws or sitting judges, or casting doubt upon their applicability or authority, would add uncertainty to an already tumultuous period. Hence, necessary allowances were included among the transitional provisions of both the Interim Constitution and the 1996 Constitution to leave laws, regulations, judges and civil servants in place.

All law that was in force when the new Constitution took effect, continues in force, subject to... any amendment or repeal; and ... consistency with the new Constitution. ${ }^{20}$

Old order legislation that continues in force... continues to be administered by the authorities that administered it when the new Constitution took effect.... ${ }^{21}$

Every court, including courts of traditional leaders, existing when the new Constitution took effect, continues to function and to exercise jurisdiction in terms of the legislation applicable to it, and anyone holding office as a judicial officer continues to hold office

17. S. AFr. CONST. 1996, ch. 8, § 167.

18. Id. § 172(2)(a) ("The Supreme Court of Appeal, a High Court or a court of similar status may make an order concerning the constitutional validity of an Act of Parliament, a provincial Act or any conduct of the President, but an order of constitutional invalidity has no force unless it is confirmed by the Constitutional Court.").

19. See generally J.D. van der Vyver, Depriving Westminster of Its Moral Constraints: A Survey of Constitutional Development in South Africa, 20 HARV. C.R.-C.L. L. REV. 291 (1985) (contrasting South Africa's 1984 apartheid constitution with the British style of government that preceded it).

20. S. AFr. CONST. 1996, sched. 6(2)(1)(a-b).

21. Id. $(2)(2)(\mathrm{b})$. 
in terms of the legislation applicable to that office .... ${ }^{22}$

The Constitutional Court was positioned atop the preexisting legal system and empowered to oversee, guide, and correct holdover judges and judicial administrators in the application of the new rights in the starkly reformed, justice-oriented legal system. By creating a new, capstone judicial body, one untarnished by an apartheid history, South Africa was able to enjoy the ongoing benefits of an established legal system without sacrificing its transformative goals of equality, dignity, and justice. ${ }^{23}$

At the conclusion of the constitutional transition, the South African Constitutional Court was the branch of government that was undeniably the first among equals. The Court was uniquely empowered by its role to ensure the initial democratic transition and as the ultimate interpreter of the new Constitution through judicial review due to its placement at the pinnacle of a court system newly empowered by a transformational value set.

The Court's expansive power to advance substantive justice comes from institutional characteristics as much as from the generous enumeration of political and social rights. As discussed below, the Court has very broad jurisdiction over constitutional matters and has far-reaching, discretionary remedial powers. Additionally, access to the Court is multi-form and generally permissive. These procedural characteristics form a critical aspect of the power and authority of the judiciary and the Court. In some ways these qualities were necessary for a transition like South Africa's, but they also reflect the conscious vesting of authority in the Constitutional Court.

\section{B. Characteristics of the Constitutional Court's Procedural Authority}

Consistent with the Constitution and the Constitutional Court's use of plain language, the procedural authority of the Court can be thought of as the who, how, and what of constitutional justiciability in South Africa. The "who" issue concerns the persons who may bring a claim in the South African courts. The "how" issue focuses on the procedural elements of access: getting heard at the Constitutional Court by means of direct access, direct appeal, or through the standard means of traditional appellate review. The "what" issue focuses on the classic issue of subject matter jurisdiction - always an important issue for a court of limited jurisdiction like the Constitutional Court.

22. Id. (16)(1).

23. ConstitutionalCourt.org.za, supra note 6 . 


\section{Access to the Court: Who and How}

The central role of the Court is to oversee the interpretation of the Constitution by lower courts and review the constitutionality of the acts of the other governmental bodies and state actors. ${ }^{24}$ This purpose is supported by open access to the court system and broad capacity of the Constitutional Court to decide particular issues. Generally speaking, as explained below, standing rules for plaintiffs, i.e., access generally to the court system, as well as the specific rules of access to the Constitutional Court itself, are discretionary and permissive.

\section{a. Standing: Who may bring a claim?}

Access for plaintiffs is clearly spelled out in the Constitution. It includes the following very broad standing clause:

Anyone listed in this section has the right to approach a competent court, alleging that a right in the Bill of Rights has been infringed or threatened, and the court may grant appropriate relief, including a declaration of rights. The persons who may approach a court are-

(a) anyone acting in their own interest;

(b) anyone acting on behalf of another person who cannot act in their own name;

(c) anyone acting as a member of, or in the interest of, a group or class of persons;

(d) anyone acting in the public interest; and

(e) an association acting in the interest of its members. ${ }^{25}$

The constitutional grant of access for such plaintiffs extends well beyond the commonly-included classes of persons with immediate remediable harms, thus offering unquestionably greater access than most courts. $^{26}$ These standing provisions seem to anticipate the practical difficulties for many potential plaintiffs. The express allowance of access for "anyone acting ... in the interest of ... a group or class of persons" or "anyone acting in the public interest" seems to be an open invitation to anyone with resources to advance the interests of those without - a critical concern in a nation where issues of poverty, historical discrimination, and

24. S. AFr. CONST. 1996, ch. 8, § 167(4).

25. Id. ch. $2, \S 38$.

26. E.g., the American standing requirements of injury, causation, redressability, as well as the judicially-created elements of standing, drawn from U.S. CONST. art. III, § 2, cl. 1. 
poor education would otherwise inhibit access to the justice system. ${ }^{27}$ The result is that a far greater number of concerns may be brought to the attention of South African courts - assisting the Court's role as supervisor of all governmental action and granting it more opportunities to facilitate transformation.

\section{b. Access: How do claims get to the Constitutional Court?}

Although standing rules for the court system are generally permissive and an unusual form of direct access is available to plaintiffs, the Constitutional Court is meant primarily to be an appellate body. Three forms of appeal can get a case to the Court: (1) ordinary appeals from the Supreme Court of Appeal; (2) direct appeals from a High Court (or other trial court with particular jurisdiction, e.g., Land Claims Court); and (3) appeals against an order of invalidity of Parliamentary or provincial acts or the conduct of the President. ${ }^{28}$ The most common form of appeal, and the way in which most cases come before the Constitutional Court, is the standard, most recognizable form of appeal: review of a decision of the Supreme Court of Appeal, the highest appellate court for non-constitutional issues. ${ }^{29}$ Such appeals are discretionary for the Court and are determined based on consideration of the interests of justice. ${ }^{30}$

Alternatively, the Constitution allows an expedited procedure for exceptional cases: a direct appeal permits a party to appeal from the original trial court directly to the Constitutional Court. ${ }^{31}$ For most disputes, a direct appeal merely skips one level of appellate review, the Supreme Court of

27. Many people in South Africa still live in poverty and disadvantage: $9-10 \%$ of adults have had no formal education and another $10-11 \%$ are "functionally illiterate." SOUTH AFRICA YEARBOOK 2007/08, at 183 (Delien Burger, ed. 2007), available at http://www.gcis.gov.za/ resource_centre/sa info/yearbook/2007-08.htm. Only $14.6 \%$ of the population is covered by a formal medical aid scheme. Id. at 336. The unemployment rate was $25.6 \%$ in 2006 . Id. at 138 . Approximately, $71.14 \%$ of households rent housing and approximately $28 \%$ of renters in metropolitan areas do not live in formal structures. Id. at 351.

28. S. AFr. CONST. 1996, ch. $8, \S 167(5)$.

29. Id. ch. $8, \S 168$.

30. Khumalo \& Others v Holomisa 2002 (5) SA 401 (CC) at para. 8 (S. Afr.) ("Constitution intends that the interests of justice (coupled with leave of this Court) be the determinative criterion for deciding when appeals should be entertained by this Court.").

31. R. CONST. CRT. S. AFR. 19, available at http://www.constitutionalcourt.org.za/site/ thecourt/rulesofthecourt.htm. The Constitutional Court employs an "interests of justice" evaluation, considering the prospect of success, effect of time and costs for the normal route of appeal, of direct applicability of constitutional law, and the desirability of reaching an end to any present legal uncertainty. Member of the Executive Council for Development Planning and Local Government, Gauteng v Democratic Party 1998 (4) SA 1157 (CC) at para. 16 (S. Afr.), available at http://www. saflii.org/za/cases/ZACC/1998/9.pdf. 
Appeal, but it is available from any court. ${ }^{32}$ However, the Constitutional Court denies most applications for direct appeals because they "deny to this Court the advantage of having before it judgments of the [Supreme Court of Appeals] on the matters in issue." ${ }^{\text {"3 }}$ Moreover, because of the potential that Supreme Court of Appeal adjudication will settle the claims on a nonconstitutional basis, the Court has said, "Where there are both constitutional issues and other issues in the appeal, it will seldom be in the interests of justice that the appeal be brought directly to this Court." 34

All High Courts, the Supreme Court of Appeals, and certain other courts have the capacity to "make an order concerning the constitutional validity of an Act of Parliament, a provincial Act or any conduct of the President," but any such ruling requires Constitutional Court confirmation. ${ }^{35}$ A declaration of invalidity is only valid after Court review. ${ }^{36}$ Such referrals account for much of the docket of the Constitutional Court.

Additionally, "direct access" is an exceptional (and rare) shortcut procedure available to plaintiffs with its origin in the Constitution: "National legislation or the rules of the Constitutional Court must allow a person, when it is in the interests of justice and with leave of the Constitutional Court... to bring a matter directly to the Constitutional Court ...."37 The "direct access" procedure is a discretionary jurisdictional procedure for the Court. In practice, the Court has allowed direct access only in very limited circumstances. The Court has exhibited a preference for the traditional appellate process as the means through which a case should rise to the Court's attention. ${ }^{38}$

Although direct access (like a direct appeal) is granted only in very exceptional circumstances, its availability allows the Constitutional Court

32. CONST. Cт. S. AFR. R. 19(1), available at http://www.constitutionalcourt.org.za/site/ thecourt/rulesofthecourt.htm.

33. Gauteng, 1998 (4) SA at para. 32.

34. Id.

35. S. AfR. Const. 1996, ch. 8, § 172(2)(a) ("The Supreme Court of Appeal, a High Court or a court of similar status may make an order concerning the constitutional validity of an Act of Parliament, a provincial Act or any conduct of the President, but an order of constitutional invalidity has no force unless it is confirmed by the Constitutional Court.").

36. Such an order is mandatory and must occur within fifteen days of its declaration. JOHAN DE WAal et al., The Bill of Rights HandBoOK CH. 5.4 (2000). Such a referral is treated differently than an appeal or a grant of direct access. Id. The parties to the original action may file an appeal of the ruling or apply for confirmation of it. Id. If this happens, the Court will follow the normal appellate procedure. Id.

37. S. AFR. CONST. 1996, ch. 8, § 167(6)(a).

38. See generally Mkontwana v Nelson Mandela Metropo. Municipality \& Others 2005 (1) SA 530 (CC) (S. Afr.) (discussing how direct access is not normally in the interest of justice and how other courts' views assist the Court in making decisions). 
discretion to expedite a judicial determination when the parties' circumstances or the requirements of justice warrant it. ${ }^{39}$ The new Constitution's legal system has flexibility structured into it for when the traditional (and slow) trial or appellate process is insufficient for the demands of justice. Of note, the companion case to Minister of Home Affairs $v$ Fourie, discussed below, is one such exception. ${ }^{40}$ Direct access was granted because the "overlap between the issues raised [in the two marriage equality cases] and their strong interconnectedness requires them to be dealt with in an integrated and comprehensive fashion." ${ }^{\prime 1}$

\section{Jurisdiction: What Claims Can Be Adjudicated?}

The 1996 Constitution, like the Interim Constitution before it, envisions a highly influential role for the Constitutional Court. The Constitutional Court "is the highest court in all constitutional matters," 42 with such matters being defined non-exclusively as "including any issue involving the interpretation, protection, or enforcement of the Constitution."43 Its authority is limited to "constitutional matters, and issues connected with decisions on constitutional matters," but the Court has exclusive competence to decide the jurisdictional appropriateness of any issue before

\section{S. AFr. CONST. 1996, ch. $8, \S 167(6)$.}

40. Minister of Home Affairs \& Another v Fourie \& Another 2005 (1) SA 524 (CC) at paras. 39-44 (S. Afr.), available at http://www.saflii.org/za/cases/ZACC/2005/19.pdf. The companion case, joined at the Constitutional Court, was Lesbian and Gay Equality Project \& Others $v$ Minister of Home Affairs \& Others 2006 (1) SA 524 (CC) (S. Afr.), available at http://www.saflii.org/za/ cases/ZACC/2005/20.pdf.

41. Fourie 2005 (1) SA at para 42. Other exceptions are discussed in Tsotetsi v Mut. \& Fed. Ins. Co. 1997 (1) SA 585 (CC) at para. 12 (S. Afr.), available at http://www.saflii.org/za/cases/ ZACC/1996/19.pdf (explaining that " $[\mathrm{t}] \mathrm{he}$ court has been willing to exercise its discretion to permit direct access in several cases: where it was satisfied that there was a pressing need for a particular issue to be determined in order to avoid substantial dislocation in the criminal justice process $(S v$ Zuma at paragraph 11); or to prevent significant delays and disruption in the procedures relating to the liquidation of companies (Ferreira $v$ Levin NO and Others; Vryenhoek and Others $v$ Powell NO and Others at paragraph 10); where a litigant had no other avenue for relief available (Besserglikv Minister of Trade, Industry and Tourism and Others at paragraph 6); where there was a compelling national interest in the determination of an issue in the light of a pending election (Executive Council of the Western Cape Legislature and Others v President of the Republic of South Africa and Others at paragraphs $15-17$ [sic]) and where parties consented to direct access and there was a real prospect that the order made by the court will in fact be decisive for the case (Brink $v$ Kitshoff NO at paragraph 18). The grant of direct access remains a discretionary power of the court which will be exercised in exceptional circumstances only and in the light of the facts of each particular application.").

42. S. Afr. CONST. 1996, ch. 8, § 167(3).

43. Id. (7). 
it. $^{44}$

The South African judiciary is a decentralized system of judicial review; multiple layers of courts may review laws, regulations, and state and private action against the dictates of the 1996 Constitution. The constitutional review authority of the lower South African courts is defined as all constitutional matters other than those belonging to the exclusive jurisdiction of the Constitutional Court. ${ }^{45}$ Hence, it is most helpful first to review the areas of exclusive jurisdiction:

Only the Constitutional Court may-

(a) decide disputes between organs of state in the national or provincial sphere concerning [their] constitutional status, powers or functions ...;

(b) decide on the constitutionality of any parliamentary or provincial Bill [under its abstract review authority ${ }^{46}$ ] . . ;

(c) decide applications [for declaration of unconstitutionality of

Parliamentary or provincial acts] ...;

(d) decide on the constitutionality of any amendment to the Constitution;

(e) decide that Parliament or the President has failed to fulfil a constitutional obligation; or

(f) certify a provincial constitution ... ${ }^{47}$

Hence, the Court is granted all of the varieties of jurisdiction - original jurisdiction, appellate jurisdiction, and abstract review authority-rather than some smaller set as is typical in most other legal systems. For matters of exclusive jurisdiction, the Court will be the venue of original and final review. All other matters, including the majority of constitutional validity claims, will typically be heard by other courts and reach the Constitutional Court only on appeal or by direct referral from the lower court.

\section{Remedial Powers}

Like the laws regarding standing and access to the courts and its jurisdictional grant, the remedial powers of the Constitutional Court (and the South African courts generally) are very broad - both in initial grant and in their interpretation by the Court itself. Section 172 of the Constitution states:

44. Id. (3).

45. Id. $\S 169-70$.

46. Id. ch. 4, §§ 79-80, 121-22.

47. Id. ch. $8, \S 167(4)$. 
When deciding a constitutional matter within its power, a court(a) must declare that any law or conduct that is inconsistent with the Constitution is invalid to the extent of its inconsistency; and (b) may make any order that is just and equitable, including -

(i) an order limiting the retrospective effect of the declaration of invalidity; and

(ii) an order suspending the declaration of invalidity for any period and on any conditions, to allow the competent authority to correct the defect. ${ }^{48}$

These provisions stress the two, often distinct, aspects of remedies in constitutional cases: the reviewing court must invalidate actions or laws it finds to be unconstitutional, and it may make any "just and equitable" remedial order to the successful party. Both of these elements are important for a legal system focused on substantive justice. The mandatory element ensures the enforcement of the new constitutional values - and is a requirement notably placed on all courts, not just on the Constitutional Court. The permissive element allows great latitude for the courts to ensure their remedies address more than merely formal equality or negative liberties. The breadth of the remedial options means that the courts are free to advance genuine fairness and justice in their orders.

\section{a. Invalidation of Unconstitutional Legislation and Conduct}

A declaration of invalidity is a non-discretionary remedy for the reviewing court once it determines the relevant legislation or conduct is unconstitutional. ${ }^{49}$ Such a requirement encourages the reformation of the legal system under the new constitutional values. This action is limited only by a court's capacity to avoid constitutional issues in settling the dispute directly before it or to reasonably interpret the provision as consistent with the Constitution. ${ }^{50}$ These elements of judicial restraint have been evident in the jurisprudence of the Constitutional Court since its earliest cases. ${ }^{51}$

48. S. AFr. CONST. 1996, ch. 8, § 172(1).

49. Id. (1)(a).

50. In State v Mhlungu, the court stated, "as a general principle . . . where it is possible to decide any case, civil or criminal, without reaching a constitutional issue, that is the course which should be followed." State v Mhlungu 1995 (3) SA 867 (CC) at para. 59 (S. Afr.); see also State v Dlamini 1999 (7) BCLR 771 (CC) at para. 27 (S. Afr.). The Court has held that the doctrine is to be observed by lower courts and the Constitutional Court itself. State v Bequinot 1997 (2) SA 887 (CC) at para. 14 (S. Afr.).

51. Mhlungu 1995 (3) SA at para. 59. 


\section{b. Just and Equitable Remedial Orders}

In several cases, the Court has declared that, in principle, it has all necessary powers to fashion any appropriate remedy. ${ }^{52}$ In selecting a remedy, the requisite balancing will include weighing: (1) the objective of the remedy ("to address the wrong occasioned by the infringement"); (2) the value of deterrence of future violations of the right; (3) realistic compliance issues; and (4) fairness to all affected. ${ }^{53}$ South Africa's history of human rights violations and the practical difficulty of bringing cases to the Constitutional Court are presented as justifications for generous remedies in human rights cases:

I have no doubt that this Court has a particular duty to ensure that, within the bounds of the Constitution, effective relief be granted for any of the rights entrenched in it. In our context an appropriate remedy must mean an effective remedy, for without effective remedies for breach, the values underlying and the rights entrenched in the Constitution cannot properly be upheld or enhanced. ${ }^{54}$

The Court's judgments often portray its remedial power as the core of its constitutional duty. And the Court's authority and obligation to produce just remedies call upon the justices to seek solutions that reach beyond traditional remedies:

Depending on the circumstances of each particular case the relief may be a declaration of rights, an interdict, a mandamus or such other relief as may be required to ensure that the rights enshrined in the Constitution are protected and enforced. If it is necessary to do so, the courts may even have to fashion new remedies to secure the protection and enforcement of these all important rights. ${ }^{55}$

In the Njongi case, discussed below, the Court critiques the executive

52. Hoffmann v S. African Airways 2000 (1) SA 1 (CC) at para. 42 (S. Afr.), available at http://www.saflii.org/za/cases/ZACC/2000/17.pdf.

53. Id. at para. 45 .

54. Fose v Minister of Safety and Sec. 1997 (3) SA 786 (CC) at para. 69 (S. Afr.), available at http://www.saflii.org/za/cases/ZACC/1997/6.pdf.

55. Id. at para. 19; see also Hoffmann, 2000 (1) SA at para. 45 (describing the process for fashioning appropriate relief: "The determination of appropriate relief, therefore, calls for the balancing of the various interests that might be affected by the remedy. The balancing process must at least be guided by the objective, first, to address the wrong occasioned by the infringement of the constitutional right; second, to deter future violations; third, to make an order that can be complied with; and fourth, of fairness to all those who might be affected by the relief. Invariably, the nature of the right infringed and the nature of the infringement will provide guidance as to the appropriate relief in the particular case."). 
branch officials for failing to consider the "moral choice" related to their administrative responsibilities. ${ }^{56}$ For the Court, decisions about remedies seem to involve the moral elements of the judicial role. As Justice O'Regan has stated, "The power and duty to protect constitutional rights is conferred upon the courts and courts should not shrink from that duty." 57

Neither the critical importance of the remedial power to the Court nor the statements of the Court that it must "strike effectively" at the source of the "constitutional infringement" has meant that there are not principled limitations on the remedies granted. ${ }^{58}$ Section 172 has not provided fodder for unrestrained generosity on the part of the Court. Most particularly, remedies related to state resources have evoked caution from the Court: "The court would not lightly make an order the effect of which would be to grossly distort the financial affairs of [the state]." ${ }^{.59}$ The Court occasionally appears to be looking over its shoulder at a long line of potential claimants to the immediate remedy. ${ }^{60}$

The socio-economic rights jurisprudence of the Court has highlighted both the expansiveness and the restraint in the Court's use of its remedial power. In general, the core social welfare rights cases ${ }^{61}$ affirm that the Court

56. Njongi v Member of the Executive Council, Dep't of Welfare, Eastern Cape 2008 (4) SA 237 (CC) para. 78 (S. Afr.), available at http://www.saflii.org/za/cases/ZACC/2008/4.pdf.

57. Minister of Home Affairs \& Another v Fourie \& Another 2005 (1) SA 524 (CC) at para. 171 (S. Afr.).

58. Fose 1997 (3) SA at para. 96. On occasion, under authority of the Constitution, the Court has made exceptions to this rule - or to the normal non-retroactivity of judgments generally - as required by interests of justice. The Constitution grants this authority. S. AFR. CONST. 1996, sched. $6, \S 16(6)(a)$.

59. Tsotetsi v Mut. \& Fed. Ins. Co. 1997 (1) SA 585 (CC) at para. 9 (S. Afr.). But see State v Bhulwana 1996 (1) SA 388 (CC) at para. 399 (S. Afr.) ("It is only when the interests of good government outweigh the interests of the individual litigants that the Court will not grant relief.").

60. The Court's remedial authority also extends to the awarding of costs. Costs will be considered cautiously in order to balance promotion of legitimate rights litigation and discouragement of frivolous suits. See Motsepe v Comm'r for Inland Revenue 1997 (6) BCLR 692 (CC) at para. 30 (S. Afr.). Notably, the Court has also sought to avoid the "chilling" effect of imposing costs against citizen litigants who have sought to uphold their right against the state.

61. See, e.g., Soobramoney v Minister of Health (Kwazulu-Natal) 1998 (1) SA 765 (CC) (S. Afr.), available at http://www.saflii.org/za/cases/ZACC/1997/17.pdf (discussing right of access to health care and emergency medical treatment for terminally ill patient); Government of the Republic of South Africa \& Others v Grootboom \& Others 2000 (1) SA 46 (CC) (S. Afr.) [hereinafter Grootboom], available at http://www.saflii.org/za/cases/ZACC/2000/19.pdf (discussing right of access to adequate housing for unlawful squatters); Minister of Health $v$ Treatment Action Campaign (No. 2) 2002 (5) SA 721 (CC) (S. Afr.) [hereinafter TAC], available at http://www.saflii.org/za/cases/ZACC/2002/15.pdf (discussing health care rights in context of mother-to-child HIV transmission). For a discussion of the most judgments (including lower court judgments) related to socio-economic rights, see the Socio-Economic Rights Project of the Community Law Centre's Case Reviews, http://www.communitylawcentre.org.za/clcprojects/socio-economic-rights/case-reviews/south-african-cases/ (last visited Apr. 10, 2010). 
will require implementation that includes "all reasonable steps that are necessary to initiate and sustain" a broad, policy-based program to advance social welfare with particular attention paid to those who are most vulnerable, ${ }^{62}$ but the "obligations imposed on the state... are dependent upon the resources available for such purposes." ${ }^{\circ 3}$

The potential reach of the Court remedies was demonstrated in the Treatment Action Campaign (TAC) case in 2002. The far-reaching court order in $T A C$ required the government to "devise and implement within its available resources a comprehensive and co-ordinated programme" to address mother-to-child HIV transmission issues. ${ }^{64}$ It ruled that the program must include reasonable measures for counseling and testing pregnant women for HIV, must immediately remove the restrictions that prevented HIV prevention medication from being distributed widely, and must "permit and facilitate" the use of such medication for the purpose of reducing the transmission of HIV. ${ }^{65}$

The demonstration of restraint has also been evident in the Court's social welfare cases. Typically, the Court has focused on dissatisfaction with governmental programs or governmental action, thereby placing the burden on the government to improve its programs, generally without reference to the parties who advanced the claims to the Court. The Court's remedial orders essentially tell the government to do better, rather than ensuring any immediate improvement for the complainant. ${ }^{66}$ Typical of the Court's remedies is Grootboom, where the Court declared the Western Cape's housing program unconstitutional but issued an order that brought no immediate or direct relief to Irene Grootboom or the hundreds of other plaintiffs. ${ }^{67}$ And, although this remedial modesty in social welfare cases has been the basis for significant criticism of the Court, it nevertheless highlights the flexible capabilities of the Court's remedial authority.

It is this capacity for expansive remedies, combined with the broad discretion to choose an appropriate remedy, that empowers the Court to advance substantive justice. These remedial powers, as well as the other

62. Grootboom 2000 (1) SA at para. 67.

63. Soobramoney 1997 (1) SA at para. 11.

64. TAC 2002 (5) SA at para. 135.

65. Id.

66. Christiansen, supra note 4 , at $380-84$.

67. Grootboom 2000 (1) SA at para. 99; see also Kameshni Pillay, Implementing Grootboom: Supervision Needed, 3 ESR REV. 11 (2002), available at http://www.escr-net.org/usr_doc/ Kameshni_Pillay___Implementing_Grootboom.doc (explaining that, although Grootboom was legally significant, its practical effect was limited); Lucie White, African Lawyers Harness Human Rights to Face Down Global Poverty, 60 ME. L. Rev. 165, 170-71 (2008) (describing Ms. Grootboom's post-trial frustration). 
elements of judicial authority and institutional capacity, reflect the unique role of the Court within the post-apartheid state and the particular constitutional dispensation for the Court - to facilitate the transformation of the nation.

\section{Characteristics of the Constitutional Court's Interpretive Mandate}

Unusually, at least to American commentators, the South African Constitution provides substantial guidance in its own interpretation and in the interpretation of South African law generally: ${ }^{68}$

(1) When interpreting the Bill of Rights, a court, tribunal or forum-

(a) must promote the values that underlie an open and democratic society based on human dignity, equality and freedom ....

(2) When interpreting any legislation, and when developing the common law or customary law, every court, tribunal or forum must promote the spirit, purport and objects of the Bill of Rights. ${ }^{69}$

The "spirit, purport and objects" of the Constitution are identified throughout the text. The Preamble asserts that the Constitution is adopted in order to "establish a society based on democratic values, social justice and fundamental human rights... [and] [i]mprove the quality of life of all citizens and free the potential of each person ...." ${ }^{70}$ Even more pointedly, the first section of the Constitution, located in the first chapter (called "Founding Provisions"), states:

The Republic of South Africa is ... founded on the following values:

(a) Human dignity, the achievement of equality and the advancement of human rights and freedoms.

(b) Non-racialism and non-sexism.

(c) Supremacy of the constitution and the rule of law.

68. Famously, the U.S. Constitution provides little guidance beyond what can (sometimes controversially) be inferred from the use of broad descriptive language and the Ninth Amendment. U.S. CONST., amend. IX ("The enumeration in the Constitution, of certain rights, shall not be construed to deny or disparage others retained by the people.").

69. S. AFR. CONST. 1996, ch. $2, \S 39(2)$. This replaced a provision in the Interim Constitution that explicitly called for "reading down," a process through which "a more restricted interpretation which does not exceed such [constitutional] limits" was applied wherever possible. S. AFR. (Interim) CONST. ch. 3, § 35(2). Other references to the role of South Africa's constitutional values appear in the Constitution, for example, "[p]ublic administration must be governed by the democratic values and principles enshrined in the Constitution ...." S. AFR. CONST. 1996, ch. 10, $\S$ 195(1).

70. Id. at pmbl. 
(d) Universal adult suffrage ... to ensure accountability, responsiveness and openness. ${ }^{71}$

And similarly core guidance is provided in the first section of Chapter Two, The Bill of Rights:

1. This Bill of Rights is a cornerstone of democracy in South Africa. It enshrines the rights of all people in our country and affirms the democratic values of human dignity, equality and freedom.

2. The state must respect, protect, promote and fulfil [sic] the rights in the Bill of Rights. ${ }^{72}$

These are the constitutional values that animate the post-apartheid transformation. The South African Constitutional Court has taken such constitutional guidance to heart. From its earliest cases, the Court has expressly viewed its interpretive role as "an approach which, whilst paying due regard to the language that has been used, is 'generous' and 'purposive' and gives expression to the underlying values of the Constitution." "73

To explain the meaning of its interpretive method, the Court has frequently cited the famous description of purposive interpretation by Judge Brian Dickson (who later became the Chief Justice of Canada) in Regina $v$. Big M Drug Mart Ltd., a case discussing the appropriate interpretation of rights under the Canadian Charter of Rights. ${ }^{74}$ Judge Dickson stated that the proper meaning of a right is:

ascertained by an analysis of the purpose of such a guarantee; it [is] to be understood, in other words, in the light of the interests it was meant to protect.

In my view this analysis is to be undertaken, and the purpose of the right or freedom in question is to be sought, by reference to the character and larger objects of the Charter itself, to the language chosen to articulate the specific right or freedom, to the historical origins of the concept enshrined, and where applicable, to the meaning and purpose of the other specific rights and freedoms with which it is associated within the text .... The interpretation should be ... a generous rather than a legalistic one, aimed at

71. Id. ch. $1, \S 1$

72. Id. ch. $2, \S 7(1)-(2)$. Also, provincial constitutions and amendments to them "must comply with the values in section 1 and with Chapter 3." Id. ch. 6, § 143(2)(a).

73. Sv Makwanyane \& Another 1995 (3) SA 391 (CC) at para. 9 (S. Afr.), available at http://www.saflii.org/za/cases/ZACC/ 1995/3.pdf (attributing this understanding to the Canadian Charter case Regina v. Big M Drug Mart Ltd., [1985] 1 S.C.R. 295 (Can.)).

74. See, e.g., Makwanyane 1995 (3) SA at para. 9; State v Zuma \& Others 1995 (2) SA 642 (CC) at para. 15 ("This must be right."). 
fulfilling the purpose of the guarantee and securing for individuals the full benefit of the Charter's protection. ${ }^{75}$

Such an interpretive method, especially when coupled with the postapartheid setting and express transformational values of the South African Constitution, grants tremendous discretion and power to the Constitutional Court. $^{76}$

\section{External Authority over the Judiciary}

A final note worth mentioning is that the power of the Court is only minimally constrained by external forces. Legally, the Court is working from a very clean slate. It is a new institution interpreting a new Constitution in a new democracy. Even now, it must reconcile its judgments with fewer than fifteen years of precedents. Its frequent reviews of foreign and international law ${ }^{77}$ do little to constrain the outcome of its cases because typically the Court reviews similar opinions as support for its conclusions and reviews contrary holdings merely to differentiate them from South African circumstances. ${ }^{78}$

75. Regina v. Big M Drug Mart Ltd., [1985] 1 SCR 295, 344 (Can); see, e.g., Makwanyane 1995 (3) SA at para. 9; State v Zuma \& Others 1995 (2) SA 642 (CC) at para. 15 ("This must be right.").

76. Complementing this preference for generous interpretation of rights, the desire to advance the transformative constitutional values is even present in the guidelines to the Court for when rights may appropriately be limited under the Constitution's Limitations Clause. Like many constitutions, but notably not the United States Constitution, the South Africa Constitution has a general limitations clause that identifies criteria for examining whether a particular violation of an enumerated right is nevertheless acceptable under other, broader constitutional principles. The South Africa Constitution states:

1. The rights in the Bill of Rights may be limited only in terms of law of general application to the extent that the limitation is reasonable and justifiable in an open and democratic society based on human dignity, equality and freedom, taking into account all relevant factors, including

a. the nature of the right;

b. the importance of the purpose of the limitation;

c. the nature and extent of the limitation;

d. the relation between the limitation and its purpose; and

e. less restrictive means to achieve the purpose.

2. Except as provided in subsection (1) or in any other provision of the Constitution, no law may limit any right entrenched in the Bill of Rights.

S. AFR. CONST. 1996, ch. $2, \S 36$.

77. Id. § 39(1) ("When interpreting the Bill of Rights, a court, tribunal or forum . . . (b) must consider international law; and (c) may consider foreign law.").

78. Jolyon Ford, Some Reflections on a Decade of International and Comparative Influence on the Rights Jurisprudence of the Constitutional Court of South Africa, in CONSTITUTIONAL 
Political control over the Court is also extremely limited. The judges serve for fixed, non-renewable terms and can be removed only by a declaration of "gross incompetence" or "gross misconduct" by the politically independent Judicial Service Commission in conjunction with a super-majority of the National Assembly. ${ }^{79}$ Such a procedure seems highly unlikely to succeed outside of the gravest of offenses. And indeed no judge has been subjected to the Article 177 removal procedure. ${ }^{80}$ So far, the political branches have not become involved in judicial decision-making. The Court has been free to set its own limits on its authority-or work without them.

\section{Recent Substantive Justice Cases at the Constitutional Court}

Study of the textual grant of judicial authority and the pervasiveness of enforceable post-apartheid values reveals a powerful and influential court. The Constitutional Court has been empowered through its history and its governing document to facilitate South Africa's transition and transformation. First, it was given a unique role in facilitating the transition from apartheid to democratic constitutionalism, required to validate its own governing document through the certification process, and assigned an ongoing role enforcing the constitutional elements of the negotiations that ended apartheid. Second, it was assigned the continuing task of ensuring South Africa's transformation into a human rights state, which it accomplishes through constitutional judicial review over lower court decisions and governmental action generally.

But the institutional capacities of the Court lie dormant until applied in real cases. Since its formation in 1995, the Court has decided a host of critically important cases related to both social welfare rights and civil and political rights. ${ }^{81}$ Many of these cases have supported the deeper dimensions of justice than are typical in legal systems focused exclusively on formal equality and negative liberties. This Section highlights three recent cases in which the Court has used its unique procedural and interpretive powers to facilitate justice in unusual circumstances or through novel means. Each case emphasizes several effective means of advancing substantive justice

DemOCRACY IN South Africa 1994-2004, 13-17 (Max du Plessis \& Steven Pete, eds., 2004).

79. E.g., S. AFR. CONST. 1996, ch. 8, § 177(1) (“A judge may be removed from office only if "a. the Judicial Service Commission finds that the judge suffers from an incapacity, is grossly incompetent or is guilty of gross misconduct; and b. the National Assembly calls for that judge to be removed, by a resolution adopted with a supporting vote of at least two thirds of its members.").

80. See Dept. of Justice \& Const. Dev., Judicial Serv. Comm'n Annual Reports, available at $\mathrm{http}: / / \mathrm{www} . d o j . g o v z a /$ reports/report_list.html.

81. For a detailed discussion of these important cases see Christiansen, supra note 4, at 356 73. 
that are available to the Constitutional Court.

\section{A. Leveraging Parliament to Advance Substantive Equality in Fourie}

In 1994, South Africa became the first country to expressly include legal protections for gays and lesbians in its national constitution. ${ }^{82}$ The South African Equality Clause requires "equal protection and benefit of the law" including the "full and equal enjoyment of all rights and freedoms" for "everyone," and it prohibits governmental and private discrimination "directly or indirectly against anyone on one or more grounds, including ... sexual orientation." 83 The road to marriage equality for same-sex couples in South Africa's Fourie case was a direct consequence of these protections, ${ }^{84}$ but that case is only one of several equality cases related to sexual orientation that the Court has decided.

82. The historical discussion that follows relies heavily on a longer work. See generally Eric C. Christiansen, Ending the Apartheid of the Closet: Sexual Orientation in the South African Constitutional Drafting Process, 32 NYU J. INT'L L. \& POL. 997 (2000) (identifying a three-part explanation for the South African constitution's unprecedented protections for gays and lesbians and proposing insights other countries might draw from the experience).

83. Both the Interim Constitution and the final Constitution expressly prohibited discrimination on the basis of sexual orientation. The final Constitution's Equality Clause states:

1. Everyone is equal before the law and has the right to equal protection and benefit of the law.

2. Equality includes the full and equal enjoyment of all rights and freedoms ...

3. The state may not unfairly discriminate directly or indirectly against anyone on one or more grounds, including race, gender, sex, pregnancy, marital status, ethnic or social origin, colour, sexual orientation, age, disability, religion, conscience, belief, culture, language, and birth.

4. No person may unfairly discriminate directly or indirectly against anyone on one or more grounds in terms of subsection (3). National legislation must be enacted to prevent or prohibit unfair discrimination.

5. Discrimination on one or more of the grounds listed in subsection (3) is unfair unless it is established that the discrimination is fair.

S. AFr. CONST. 1996, ch. 2 , $\$ 9$ (emphasis added); S. AFr. (Interim) Const. ch.3, § 8.

84. Minister of Home Affairs \& Another v Fourie \& Another 2005 (1) SA 524 (CC) at para. 76 (S. Afr.). The Equality Clause itself was the culmination of the African National Congress (ANC) political ideology of non-racialism. Although many South Africans, including many ANC members, opposed the notion that its non-discrimination principles extended to gays and lesbians, gay rights groups relied heavily on the ANC during the drafting of the Constitution. Non-racialism is a radical view of fundamental human rights and non-discrimination shaped by a history of violence-enforced, state-led discrimination in all areas of fundamental human activity for decades. Const. Comm., African Nat'L Cong., A Discussion Document on Structures and PrinCiPles of A CONSTITUTION FOR A DeMOCRATIC SOUTH AFrica 13-14 (1991), quoted in Peter N. Bouckaert, The Negotiated Revolution: South Africa's Transition to a Multi-Racial Democracy, 33 STAN. J. INT’L L. 375, 399-400 (1997). 


\section{Gay and Lesbian Equality in the Constitutional Court}

In the 1998 decision of NCGLE v Minister of Justice (NCGLE Sodomy case), the South African Constitutional Court decriminalized consensual same-sex sexual activity between adult men. ${ }^{85}$ Writing for the Court, Justice Ackermann held that the common law and statutory offenses of sodomy violate the equality, dignity, and privacy rights of the South African Constitution. Concurring, Justice Albie Sachs stated, "Although the Constitution itself cannot destroy homophobic prejudice it can require the elimination of public institutions which are based on and perpetuate such prejudice." $" 86$

The NCGLE Sodomy case began a trend. Over the next five years, the Court handed down four additional rulings related to the rights of lesbians and gay men. ${ }^{87}$ Each was a unanimous decision by the Court; each was a victory for the gay plaintiffs; and each reaffirmed the Court's fundamental commitment to a generous interpretation of the Equality Clause as it applied to sexual minorities. In the 1999 NCGLE Immigration case, the Court ruled that the equality protections required that a "partner, in a permanent samesex life partnership" be entitled to treatment equal to that of a married heterosexual spouse for the purposes of immigration law. ${ }^{88}$ In the 2002 Satchwell case, the Court held that the government must afford to same-sex partners of South African judges the same employment benefits provided to opposite-sex spouses. ${ }^{89}$ In the DuToit case in 2003, the Court ruled that denial of second-parent adoption rights to gay couples was a violation of their constitutional rights to equality and dignity in addition to being a violation of the "best interests of the child" standard required by the child

85. Nat'l Coal. for Gay and Lesbian Equal. \& Another v Minister of Justice \& Others 1998 (1) SA 6 (CC) at para. 106 (S. Afr.) [hereinafter NGLE Sodomy], available at http://www. saflii.org/za/cases/ZACC/1998/15.pdf. The unanimous decision confirmed a lower court ruling that declared unconstitutional the common law offense of sodomy and struck down provisions of the Sexual Offences Act that criminalized certain vaguely-defined acts between men. "A male person who commits with another male at a party ["any occasion where more than two persons are present"] any act calculated to stimulate sexual passion or to give sexual gratification, shall be guilty of an offence." Sexual Offences Act of 1957 s. 20A.

86. NCGLE Sodomy 1998 (1) SA at para. 129.

87. See infra notes 89-93 and accompanying text.

88. Nat'l Coal. for Gay and Lesbian Equal. \& Others v Minister of Home Affairs \& Others (NCGLE Immigration) 1999 (2) SA 1 (CC) at para. 57 (S. Afr.), available at http:// www.saflii.org/ za/cases/ZACC/1999/17.pdf.

89. Satchwell v President of the Republic of South Africa \& Another 2002 (6) SA 1 (CC) at para. 23 (S. Afr.), available at http://www.saflii.org/za/cases/ZACC/2002/18.pdf ("Inasmuch as the [Act's] provisions in question afford benefits to spouses but not to same-sex partners who have established a permanent life relationship similar in other respects to marriage, including accepting the duty to support one another, such provisions constitute unfair discrimination."). 
welfare protections of the Constitution. ${ }^{90}$ And later that year in $J$ and $B$, the Court applied the same reasoning to a case regarding adoption following artificial insemination. ${ }^{91}$

These judgments evidence the increasing frustration of the Court as a result of parliamentary inaction. ${ }^{92}$ At least since the ruling in NCLGE Immigration - if not as far back as the ratification of the Constitution with its inclusive Equality Clause - strong evidence existed that the Court would rule against sexual orientation-based discrimination in family law generally and civil marriage laws specifically. Nevertheless, Parliament had neglected to take definitive action on the issue of marriage equality - and required additional (and unequivocal) coercion by the Court before it would act.

In $J$ and $B$, the Court expressly stated its frustration with Parliament for its failure to pass legislation that would bring South African family law into compliance with the equality mandate of the Constitution: "Comprehensive legislation regularising relationships between gay and lesbian persons is necessary. It is unsatisfactory for the Courts to grant piecemeal relief to members of the gay and lesbian community as and when aspects of their relationships are found to be prejudiced by unconstitutional legislation ....".93

The Court chided Parliament for its inaction, reminding the members of Parliament that they are formally bound by the Constitution ${ }^{94}$ and that they have a constitutional duty to "respect, protect, promote and fulfil the rights in the Bill of Rights." ${ }^{\circ 5}$ The executive and legislature were therefore "obliged to deal comprehensively and timeously with existing unfair discrimination against gays and lesbians." 96

\section{Marriage Equality in the Constitutional Court}

Marie Adriaana Fourie and her girlfriend Cecelia Bonthuys had been together nearly ten years when they brought suit for legal recognition of

90. Du Toit \& Another v Minister of Welfare and Population Dev. \& Others 2003 (2) SA 198 (CC) at paras. 41-43 (S. Afr.).

91. $J \&$ Another v Dir. Gen., Dep't of Home Affairs \& Others 2003 (5) SA 621 (CC) at para. 13 (S. Afr.) [hereinafter $J$ and B], available at http://www.saflii.org/za/cases/ZACC/2003/3.pdf.

92. The fact that the government ministers did not actively oppose the gay and lesbian applicants in Satchwell, Du Toit, and $J$ and B further suggests that the government did not believe there was a viable constitutional argument in opposition to the gay rights claim.

93. J and B 2003 (5) SA at para. 23.

94. Id.

95. S. AFr. CONST. 1996, § 8(1) ("The Bill of Rights . . binds the legislature, the executive, the judiciary and all organs of state.").

96. $J$ and $B 2003$ (5) SA at para. 25. 
their relationship in the Pretoria High Court in $2002 .{ }^{97}$ The legal conclusion that the rights and privileges of marriage may not be denied on the basis of sexual orientation was, in essence, predetermined. Nearly every element of the Fourie decision had been previously decided. The Court's unanimous substantive ruling was a surprise to no one. The prohibition of same-sex marriage was unfair discrimination because it was differential legal treatment on the basis of sexual orientation. ${ }^{98}$ The Court asserted that the gay and lesbian parties to the cases sought:

the right to be acknowledged as equal and to be embraced with dignity by the law ... [that] accept[s] the reality of their presence, and the integrity in its own terms, of their intimate life .... [T] he law in the past failed to secure for same-sex couples the dignity, status, benefits and responsibilities that it accords to heterosexual couples. ${ }^{99}$

Although the substantive holding was not significantly in doubt, what was surprising was the court-ordered delay in enforcing the order of invalidity. The Court could have directly and immediately fixed the problem it had repeatedly signaled for Parliament to address in previous cases: the absence of a comprehensive legal scheme addressing same-sex family relationships. In prior cases, it had used its expansive remedial powers to invalidate discriminatory laws or to "read in" necessary language to cure a constitutional defect. ${ }^{100}$ The Court took neither option in Fourie. Rather, it declared the constitutional infirmity of existing law but held that the ruling of invalidity was suspended for one year. ${ }^{101}$ It sent the deficient law back to Parliament and gave it twelve months to "cure the defect" in the Marriage Act. ${ }^{102}$

97. Fourie \& Another v Minister of Home Affairs \& Another (Oct. 2002) No. 17280/02 (unpublished), cited in Minister of Home Affairs and Another v Fourie and Another 2005 (1) SA 524 (CC) at para. 7 (S. Afr.).

98. Fourie 2005 (1) SA 524 (CC) at paras. 78-79. ("The common law and section 30(1) of the Marriage Act continue to deny to same-sex couples equal protection and benefit of the law ... and taken together result in same-sex couples being subjected to unfair discrimination by the state . . . .).

99. Id. at para. 78 .

100. See, e.g., NCGLE Sodomy, 1998 (1) SA 6 (CC) at para. 2 (invalidating: "It is declared that section 20A of the Sexual Offenses Act, 1957 is inconsistent with the Constitution and invalid."); NCGLE Immigration 1999 (2) SA 1 (CC) at para. 98 ("[S]ection 25(5) of the Aliens Control Act 96 of 1991, is to be read as though the following words appear ....").

101. Id. at paras. $120-23$.

102. In justifying its delay, the Court highlighted that much work had been done preparing Parliament to make a decision in this area. The Court noted that the South African Law Reform Commission was finalizing a legislative report and proposal process that had allowed extensive public input, would be imminently available to the Minister of Justice and Constitutional 
Parliament was ordered to remedy the discrimination in South African family law because the "present exclusion of same-sex couples from enjoying the status and entitlements" of marriage is "unsustainable." 103 Same-sex couples may not be "subjected to marginalization or exclusion by law either directly or indirectly." ${ }^{104}$ Parliament must finally perform the task the Court had repeatedly reminded them was theirs; as Justice Sachs said in relation to the Fourie remedy: "It's not only the court's duty to protect constitutional rights. In fact, it's mainly legislative."105 As Parliament considered its options, its task was carefully circumscribed by both the general ruling in Fourie and the judgment's declaration of two mandatory "guiding principles" relevant to Parliament's assigned task. ${ }^{106}$

The first principle was that Parliament could not achieve equality by no longer recognizing any marriages between opposite-sex or same-sex couples. "Levelling [sic] down so as to deny access to civil marriage to all would not promote the achievement of the enjoyment of equality ...."107 The second principle addressed a concern that the parliamentary response would in fact produce "new forms of marginalization [sic]."108 The Court expressly rejected the apartheid-era legal claim that separate but equal is sufficient. "Ignoring the context, once convenient, is no longer permissible ...." ${ }^{109}$ The Court will not be blind to the context in which that happens; equality and dignity require a concern for "the intangibles as well as the tangibles involved." 110

\section{Fourie and Substantive Justice}

The Court's insistence on a fully equal solution to the problem of marriage discrimination evidenced its generous, purposive interpretation; the unanimous ruling leaves little question about the transformative import

\footnotetext{
Development and through her to Parliament, and that it would be a comprehensive review of the necessary legal changes for any formal recognition of same-sex family law arrangements. Fourie 2005 (1) SA at paras. 130-31. The SALRC in fact noted that the Court ruling would aid it in its recommendations to Parliament. Id. at para 129, n.124.

103. Id. at para. 147.

104. Id.

105. Joe Katz, South African Judge Addresses Gay Marriage at Swift Hall, CHI. MAROON NEws, Jan. 12, 2006, available at www.chicagomaroon.com/2006/1/12/south-african-judgeaddresses-gay-marriage-at-swift-hall.

106. Fourie 2005 (1) SA at para. 148.

107. Id. at para. 149.

108. Id.at para. 150 .

109. Id. at para. 153 .

110. Id.
} 
of the Constitution's Equality Clause. And the judgment's "guiding principles" demonstrate that the reach of equality must be substantive, i.e., it must advance more than merely formal or legal equality. ${ }^{111}$ "The crucial determinant will always be whether human dignity is enhanced or diminished and the achievement of equality is promoted or undermined by the measure concerned." 112

Additionally, the Court's decision to assign the task of realizing full marriage equality to the Parliament while at the same time narrowly circumscribing the result-and even providing a deadline for the changes ${ }^{113}$ - demonstrates an expansive and creative use of the Court's remedial authority to serve transformative constitutional values. The expected (and actual) result was that the ANC - the political standardbearers of the most notable liberation movement of the last century and the overwhelmingly dominant political party in South Africa-passed marriage equality into law in South Africa. ${ }^{114}$

The "democratic legitimacy" of a legislative resolution, ${ }^{115}$ the requirement of at least legislative support for gay and lesbian South Africans from the ANC, and the inevitable discussion of the meaning of gay rights in the context of South Africa's constitutional values dramatically supported the realization of substantive quality both domestically and internationally. The use of the Court's procedural authority and interpretative mandate complemented the content of the ruling itself to support the richer, extra-legal dimensions of equality.

\section{B. Empowering Communities in Olivia Road}

Because of the history of reprehensible use of evictions during apartheid, the 1996 Constitution and related statutes create multiple protections for even illegal occupiers of land. ${ }^{116}$ Any eviction, "a process made particularly stressful by historically-created and racially-based distortions in relation to access to land," ${ }^{117}$ must comport with Section 25(3)

\footnotetext{
111. Id. at para. 152.
}

112. Fourie 2005 (1) SA at para. 153.

113. Id. at para. 161 (providing the read-in remedy if Parliament does not act within twelve months).

114. Civil Union Act 17 of 2006 (S. Afr.). The ANC won $66 \%$ of the April 2009 vote. Barry Bearak, Final Results Show Resounding Victory for A.N.C. in South Africa, N.Y. TimES, Apr. 26, 2009 , at A13.

115. Fourie 2005 (1) SA at para. 171 (O’Regan, J., concurring).

116. S. Afr. CONST. 1996, ch. 2, §§ 25-26.

117. Residents of Joe Slovo Cmty., Western Cape v Thubelisha Homes \& Others [2009] ZACC 16 at para. 337 (Sachs, J., concurring) (S. Afr.), available at http://www.saflii.org/za/ 
of the Constitution, the right of access to housing: "No one may be evicted from their home, or have their home demolished, without an order of court made after considering all the relevant circumstances. No legislation may permit arbitrary evictions." 118 Statutory protections build upon this protection and are bounded by it. ${ }^{119}$

\section{The Olivia Road Case}

These limits on state action were the subject of the 2008 case, Occupiers of 51 Olivia Road, Berea Township v City of Johannesburg (Olivia Road), ${ }^{120}$ where Johannesburg sought to evict more than 400 occupants of two inner-city residential buildings due to unsafe and unsanitary conditions. ${ }^{121}$ The city's eviction request complied with the relevant statutory law, ${ }^{122}$ and it had acquired an eviction order from the Supreme Court of Appeal. ${ }^{123}$ However, even though Johannesburg had satisfied the legal requirements, the Constitutional Court prohibited the eviction of the current residents until the two sides to the dispute had come together in a process of "meaningful engagement" to discuss how best to address the current situation and the difficulties that would arise from the evictions. ${ }^{124}$

As described by the Court, "meaningful engagement" is a "two-way process" through which the government and private parties must "talk to

cases/ZACC/2009/16.pdf.

118. S. Afr. CONST. 1996, ch. 2 , § 26.

119. See, e.g., National Housing Code, Housing Act 107 of 1997, s. 4 (S. Afr.); Prevention of Illegal Eviction From and Unlawful Occupation of Land Act 19 of 1998 (S. Afr.).

120. Occupiers of 51 Olivia Road, Berea Twp. and 197 Main St. Johannesburg v City of Johannesburg \& Others 2008 (3) SA 208 (CC) (S. Afr.) [hereinafter Olivia Road], available at http:// www.saflii.org/za/cases/ZACC/2008/1.pdf.

121. Id. at para. 1.

122. National Building Regulations and Building Standards Act 103 of 1977, s. 12(4)(b) (occupational safety standards); Health Act 63 of 1977, s. 20 (hygienic condition standards).

123. City of Johannesburg $v$ Rand Prop. (Pty) \& Others 2007 (6) SA 417 (SCA) at para. 78 (S. Afr.). The eviction order had originally been denied by the Johannesburg High Court for failing to address the requirements of those in desperate need. City of Johannesburg $v$ Rand Properties (Pty) Ltd and Others 2007 (1) SA 78 (W) (S. Afr.) (finding that a city housing program failed to comply with the constitutional right to housing).

124. Olivia Road 2008 (3) SA 208 (CC) at para. 13 ("In these circumstances those involved in the management of the municipality ought at the very least to have engaged meaningfully with the occupiers both individually and collectively."); see also id. at paras. 9-23 ("a circumstance that a court must take into account to comply with section 26(3) of the Constitution is whether there has been meaningful engagement" prior to an eviction.); $I d$. at para. 18. Notably, arguments for such engagement were not raised by the parties at argument or in briefing. Id. at para. 9. 
each other meaningfully in order to achieve certain objectives." 125 Among the topics for discussion are the consequences of the government action, the means to alleviate any "dire consequences," and "when and how the city could or would fulfill [its housing-related, constitutional] obligations" to the residents if they were evicted. ${ }^{126}$ This requirement is meant to be satisfied by pre-litigation ${ }^{127}$ and should exhibit a "respectful face-to-face engagement or mediation" that is a "pro-active and honest endeavour to find mutually acceptable solutions." 128 As described in a later case, engagement is a "major pre-condition" for eviction, through which the challenge to "balance competing claims is partly resolved by getting the parties themselves to find functional solutions according to their respective needs and interests." 129 The Court's role is merely "establishing the parameters of what is just and equitable." "130

For the Court, the engagement requirement announced in Olivia Road is an extension of its ruling in Grootboom, the seminal housing rights case, that "[e]very step at every level of government must be consistent with the constitutional obligation to take reasonable measures to provide adequate housing." "131 Meaningful engagement is a constitutionally-based requirement derived primarily from the interrelated rights to housing and dignity. ${ }^{132}$

The City has constitutional obligations towards the occupants of Johannesburg. It must provide services to communities in a sustainable manner, promote social and economic development, and encourage the involvement of communities and community organisations [sic] in matters of local government. It also has the obligation to fulfil [sic] the objectives mentioned in the preamble to the Constitution to "[i]mprove the quality of life of all citizens and free the potential of each person". Most importantly it must

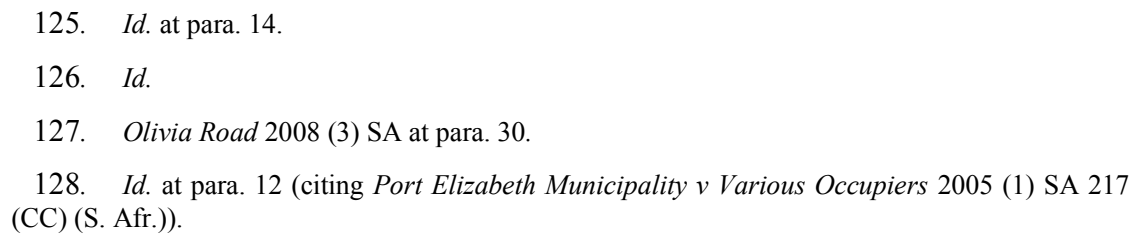

129. Residents of Joe Slovo Cmty., Western Cape v Thubelisha Homes \& Others 2009 ZACC 16 (CC) at para. 338 (S. Afr.) (Sachs, J., concurring), available at http://www.saflii.org/za/ cases/ZACC/2009/16.pdf.

130. Id.

131. Olivia Road 2008 (3) SA at para. 10 (citing Government of the Republic of South Africa \& Others $v$ Grootboom \& Others 2000 (1) SA 46 (CC) at para. 82 (S. Afr.)).

132. Grootboom 2000 (1) SA at para. 82 (cited in Olivia Road 2008 (3) SA at para. 10) ("The Constitution will be worth infinitely less than its paper if the reasonableness of State action concerned with housing is determined without regard to the fundamental constitutional value of human dignity."). 
respect, protect, promote and fulfil [sic] the rights in the Bill of Rights. ${ }^{133}$

A city that evicts without meaningful engagement "acts in a manner that is broadly at odds with the spirit and purpose of the constitutional obligations." "134

\section{Olivia Road and Substantive Justice}

The Olivia Road decision is potentially very significant. It empowers affected community members and community-oriented non-governmental organizations to affect substantive justice. Compliance with the legal requirements for eviction is necessary but not sufficient; the courts will enforce a more substantive standard. The "reasonable measures" required by the Court's purposive reading of the constitutional right of access to adequate housing must evidence that the City meaningfully engaged in an open and honest, good faith process to anticipate and address the consequences of eviction prior to evicting even unlawful residents.

In this case, as in Fourie, the Court confronted a recalcitrant governmental body - a task the Constitution empowered the Court to address effectively. It was "evident during argument that the City had made no effort at all to engage the occupiers at any time before proceedings for their eviction" despite the fact that "the City must have been aware of the possibility, even the probability, that people would become homeless as a direct result." 135 This governmental resistance justifies the placement of the burden on the state entity to present a "complete and accurate account" of meaningful engagement - in addition to demonstrating satisfaction of all statutory requirements - prior to receiving a court order for eviction. ${ }^{136}$

In Olivia Road, the Court declared a new, constitutional requirement of meaningful engagement of its own authority, supported by the new values to the post-apartheid Constitution and the expansive social welfare and dignity protections. The Court, confident of its own authority to advance the transformative values of the Constitution, established a standard for governmental entities that requires them to accommodate those values of the Constitution even when acting otherwise in conformity with existing lawthe Court empowers communities and civil society organizations to ensure their compliance.

133. Olivia Road 2008 (3) SA at para. 16 (citing S. AFR. ConST. 1996, ch. 2, §§ 7(2), 10, 11; ch. 7, § 152(1)(b-e)).
134. Id.
135. Id. at para. 13 .
136. Id. at para. 21. 


\section{Enforcing Transformational Values in Njongi}

Deliwe Muriel Njongi was an elderly, disabled woman whose only source of income since 1989 had been a state social welfare grant. ${ }^{137}$ In 1997, the Department of Welfare for the Eastern Cape terminated her benefits without notice or explanation. ${ }^{138}$ She reapplied for the grant and it was eventually reinstated in November 2000 with a token retroactive payment of R1100. ${ }^{139}$ The back-pay amount was R15,200 less than what was due to her for the period of cancellation. ${ }^{140}$ More than three years later, she initiated suit to regain the deficiency. ${ }^{141}$ During proceedings, which eventually went to the Constitutional Court, the provincial Department of Welfare paid her an additional R9400, providing no reason for withholding the remaining R5800. ${ }^{142}$

\section{The Njongi Case}

Rather than being a random, isolated incident, the treatment of Ms. Njongi was consistent with a pattern of "unlawful termination of grants."143 Lower courts had previously acknowledged that the Department of Welfare, following a flawed attempt to consolidate multiple grant recipient databases, had cancelled thousands of old-age, disability, and child support grants as a means to verify beneficiaries and acquire updated information about them. ${ }^{144}$ However, while the underlying, "unthinkably cruel" behavior of the Department of Welfare was similar in many cases throughout this period, the Court faced a different legal issue in the Njongi case. ${ }^{145}$

Because significant time had passed between the resumption of Ms.

137. Njongi v Member of the Executive Council, Dep't of Welfare, Eastern Cape 2008 (4) SA 237 (CC) at paras. 4-5 (S. Afr.).

$$
\begin{array}{cc}
138 . & I d . \\
139 . & I d . \\
140 . & I d . \\
141 . & I d .
\end{array}
$$

142. In November 2000, when Ms. Njongi's benefits were reinstated, one South African rand was worth $\$ 0.128$. At that exchange rate, the full back-pay amount of 16,300 rand was worth \$2094.58 . See Oanda Currency Converter (rate for November 30, 2000), http://www.oanda.com/ convert/classic (last visited July 18, 2009) (for conversion, enter the South African Rand amount of "Currency I have" and US dollar amount for "Currency I want" for the date of Nov. 30, 2000).

\section{Njongi 2008 (4) SA at para. 8.}

144. Id. at para. 9 .

145. Id. at para. 17 ("[T]he unlawful denial of their grants was unthinkably cruel and utterly at odds with the constitutional vision to the achievement of which that Government ought to have been committed."). 
Njongi's benefits and the present suit, the Department of Welfare asserted that the Prescriptions Act, which includes a three-year statute of limitations for claims like Ms. Njongi's, prohibited her claim. ${ }^{146}$ As straightforward as a statute of limitations claim normally is, the issue was convoluted in Njongi. ${ }^{147}$ Part of the confusion stemmed from the filings of the Department, which could, according to the Court, "generously be described as unusual" and relied heavily on a High Court case that the Court finds inapt. ${ }^{148}$

While expressing doubts (but not ultimately deciding) whether claims for constitutionally-required social grants could ever be subject to a statute of limitations defense, ${ }^{149}$ the Court concluded that the three-year prescription period had not run because, in the absence of a disavowal of the precipitating administrative decision, the partial and unexplained payment of certain amounts of back-pay was not sufficient to comprise a full reinstatement of Ms. Njongi's terminated benefits. ${ }^{150}$ Absent a full disavowal or conclusive reinstatement, she would not have known the statutory claim period had commenced. ${ }^{151}$

However, the willingness of the Court to interpret facts selectively to reach the result required by justice is not the most interesting part of the opinion for our purposes. Following the core of its rather technical judgment, the Court goes on to identify a series of specific faults in the underlying administrative action that brought the present case to the Constitutional Court. ${ }^{152}$ This part of the opinion highlights the Court's critique of the province's bureaucratic decision-making and clearly identifies areas for future claims that would advance substantive justice. ${ }^{153}$

Naturally, there are multiple factors the states must consider when

146. Act 68 of 1969, s. 12(1) (S. Afr.) ("prescription shall commence to run as soon as the debt is due").

147. Njongi 2008 (4) SA at paras. 28-39.

148. Id. at paras. 31-32 ("Not only had the defense of prescription not been raised [in Ntame] but the case was unopposed.") (citing Ntame v MEC for Social Development, Eastern Cape, and Two Similar cases 2005 (6) SA 248 (E) (S. Afr.)).

149. Njongi 2008 (4) SA 237 at para. 42 (S. Afr.) ("I have doubts whether prescription could legitimately arise when the debt that is claimed is a social grant; where the obligation in respect of which performance is sought is one which the Government is obliged to perform in terms of the Constitution; and where the non-performance of the Government represents conduct that is inconsistent with the Constitution. Despite constitutional concerns, I reluctantly conclude that this important issue should not be decided in this judgment.").

150. Id. at paras. $57-58$.

151. Id.

152. Id. at para. 60 .

153. Id. 
deciding whether to resist a claim for a rightful make-up payment. According to Njongi, one of the most important considerations is "the moral or policy issue whether the Department should use prescription to avoid paying disability grant arrears" it had incorrectly and unlawfully cancelled. ${ }^{154}$ The Court's criticism also stresses that governmental decision makers must consider the "dire inhumane consequences" 155 to the affected individual in light of her circumstances. The province's failure to comport with constitutional values was exacerbated by the lack of evidence that the province even took notice of the fact that

Mrs. Njongi is poor, that she suffers from $100 \%$ permanent disability, that she has no other source of income and that the aim of opposing the application would be to avoid paying disability grants that had accrued to her and had not been paid to her as a result of [an] unlawful administrative decision. ${ }^{156}$

The judgment ends with a strong condemnation of the provincial government, which "failed dismally in its constitutional obligations" to people in the same situation as Ms. Njongi. ${ }^{157}$ The Social Welfare Minister's decision was described as "unconscionable," 158 "grossly insulting," 159 and "a cynical decision devoid of all humanity." "T6 The Court affirmed its own capacity to set aside a minister's decision to rely on prescription, ${ }^{161}$ but the judgment focused on the more important point - the provincial officials never should have chosen to avail themselves of the prescription defense in these circumstances.

\section{Njongi and Substantive Justice}

Writing for the Njongi court, Justice Yacoob stated, "There is an inevitable and, in my view, moral choice to be made in relation to whether a debtor should plead prescription particularly when the debt is due and

\footnotetext{
154. Id. at para. 64 .

155. Njongi 2008 (4) SA at para. 70.

156. Id. at para. 66 .

157. Id. at para. 18 .

158. Id. at para. 86 .

159. Id. at para. 87.

160. Id. at para. 90 .

161. Njongi 2008 (4) SA at para. 85 ("It is not necessary in this case to decide whether the decision of the Provincial Government to invoke prescription was of such a nature that it can or ought to be set aside.").
} 
owing." ${ }^{162}$ Consideration of this moral element is a duty that the Constitution placed on all state actors. In Ms. Njongi's circumstances, some of the important considerations were her poverty and vulnerability, her disability, and the obligatory nature of the social welfare grant under the South African Constitution's social welfare provisions. ${ }^{163}$ Her circumstances should have resulted in a decision to not assert the government's statutory defense because a "decision by the State whether or not to invoke prescription in a particular case must be informed by the values of our Constitution." 164 The Court requires government entities to consider whether otherwise legal and neutral decisions are consistent with constitutional values.

A failure to consider - or perhaps to demonstrate such considerationwould violate the constitutional requirement that the values of the Constitution inform all state decision-making. This constitutional mandate means that all state administrative decisions are subject to court challenge based on their regard for constitutional values, not merely compliance with constitutional law. Indeed, the identified values of the Constitution are arguably raised to the level of enforceable law by the Njongi case.

Remedial elements of this case are also important to help ensure future compliance by government officials. In Njongi, although the Court concludes that there is insufficient basis for a punitive order against the Minister for Social Development, the Court's due consideration of that option is certainly meant as a warning to other governmental officials. ${ }^{165}$ Careful and fully informed consideration of any discretionary decision that impacts constitutional rights is clearly called for by state officials. All such decisions must be informed by the values of the Constitution-equality, dignity, and human rights. Moreover, in the area of social welfare rights, the state must remember that "[i]t is the duty of the State to facilitate rather than obstruct access to social security. This will be a fundamental consideration in making the assessment." 166

\section{AdVAnCING Substantive Justice}

In apartheid South Africa, the judiciary was a tool for enforcing the Parliamentary-based ideology of racial segregation and oppression. ${ }^{167}$ In the

\footnotetext{
162. Id. at para. 78 .

163. Id. at para. 80 .

164. Id. at para. 79.

165. Id. at para. 73.

166. Id. at para. 79 .

167. Because there was no purge of the civil service or of the judiciary at the birth of the newly
} 
new South Africa, the judiciary continues to have a critical role in enforcing state ideology but, of course, with a radically altered set of values. The postapartheid ideology is focused on South Africa as a reformed nation-not just a liberal democracy but a human rights state, which is in the process of rising to its great potential - to transform itself and be an example to other nations. ${ }^{168}$ The "new South Africa" is not only a result of the struggle against apartheid but is also a creation of the Constitution. Hence, the Constitutional Court plays the role of chief architect of a "society based on democratic values, social justice and fundamental human rights."169

The 1996 Constitution was a reaction against the apartheid ideology and the tangible effects of more than forty years of political and socioeconomic discrimination. And, because the injustice of apartheid was evidenced in more than formal legal ways, the constitutional response had to incorporate broader elements of justice. It would fail to respond fully to apartheid - fail its mission of transformative constitutionalism - if the result were only formal, legal equality. Hence, the South African Constitution goes beyond the standard civil and political rights of formal equality and negative liberty. The Constitution conceived of justice in its deeper dimensions.

For the same reason, the Constitution incorporated social welfare rights in addition to traditional civil rights. But rights to healthcare, housing, and education were not the only constitutional tools to advance substantive justice. As discussed in Part II of this Article, the desire for a transformative constitutional state also resulted in a particularly potent Constitutional Court with expansive procedural authority, an extensive remedial capacity, and a value-laden interpretive mandate. The courts were expressly granted the power of judicial review over national and provincial action and laws, and the Constitutional Court was created as a capstone court over the judiciary in order to ensure the transformation of South Africa.

The cases highlighted above show that the Court is still pursuing justice as a central player in the transformative national drama. Furthermore, the novel uses of judicial power in the cases discussed here demonstrate a potential for social justice that is a hopeful sign for the future of South Africa. This hope balances the disappointment of many commentators with the limited scope of the Court's social welfare jurisprudence. The Court has

democratic South Africa in 1994, the judges filling the courts of South Africa, now empowered to enforce the country's progressive, human rights provisions against a host of new laws issued from the first freely-elected, multi-racial Parliament were the judges appointed by and tutored in the apartheid law and parliamentary sovereignty of the previous regime. See generally DAVID Dyzenhaus, Judging the Judges, Judging Ourselves: Truth, Reconciliation and the APARTHEID LEGAL ORDER (2003) (examining the roles of judges and the judiciary during Apartheid-era South Africa).

168. S. AFr. CONST. 1996, pmbl.

169. Id. 
thought creatively and used its authority expansively to advance fuller, more generous notions of justice. I believe this may be a reason for hope that the Court will continue to use its authority to advance substantive justice. Fourie, Olivia Road, and Njongi illustrate a variety of lessons about adjudication for substantive justice. And these judgments are far from the only examples in the Court's history. ${ }^{170}$ This Section highlights, in a more generalized manner, a few of the more prominent ways in which the Court has used its constitutional authority to advance justice.

\section{A. Calling for State Action}

The first notable general action of the Court is its intentional and proactive use of its judgments and judicial orders to steer state actors to act consistently with their constitutional obligations. Courts to some element always use this guidance function; the nature of legal precedent is intended to inform private and state actors of the import of particular legal results for relatively similar parties in relatively similar situations. But the South African Constitutional Court has gone further.

The Court has encouraged, or occasionally even chided, the political branches into specific action that would advance substantive justice. The most obvious example of this occurred in the collection of gay-related equality cases that preceded the marriage equality decision in Fourie. The Court rebuked Parliament for its failure to pass "comprehensive legislation" related to family law and marriage. The consequence was that lesbian and gay South Africans had received only "piecemeal relief" in the absence of the guidance Parliament had a duty to provide. ${ }^{171}$ As multiple cases highlighted this deficiency between 1999 and 2003, the Court was no longer content to imply that Parliament should act. In the last gay rights case before Fourie, the Court pointedly declared that "[i]t is not appropriate for courts to determine [details of laws implementing marriage equality] ... Those are matters for the legislature ...."172

An even more focused version of such direction occurred when the court issued its judgment in Fourie and provided "guiding principles" that must direct any legislative resolution of unclear family law standards for

170. In addition to the many social welfare cases, other notable cases related to substantive justice cases include $M v$ State 2008 (3) SA 232 (CC) (S. Afr.) (overturning imprisonment sentence for convicted single mother due to failure of trial court to consider "best interests of the children") and Residents of Joe Slovo Cmty., Western Cape v Thubelisha Homes \& Others 2009 ZACC 16 (S. Afr.).

171. See, e.g., J and B 2003 (5) SA 621 (CC) at paras. 22-26.

172. Id. at para. 26 . 
gay and lesbian couples. ${ }^{173}$ Even the Court's decision to require a legislative remedy could be understood to show that Parliament will not escape its constitutional responsibilities through judicial resolution.

\section{B. Commandeering Other Branches of Government}

The ultimate order in the Fourie case, with its delayed judicial enforcement "to allow Parliament to correct the defects" in existing family law, further demonstrated the Court's use of its remedial power to advance substantive justice. ${ }^{174}$ Specifically, the Court's order to Parliament, which included a one-year deadline and a collection of requirements for the eventual legislation, ${ }^{175}$ leveraged the democratic authority and popularity of Parliament generally, and the ANC specifically, and bolstered the Court's judgment. ${ }^{176}$ The intended result was substantive equality, i.e., more popularly legitimized equality for same-sex couples because it was democratically legislated by the politically and culturally dominant ANC. Both the Court and Parliament seemed aware of this reason for assigning this task to Parliament rather than merely remedying the injustice through judicial fiat. ${ }^{177}$

The previous gay rights rulings had generally advanced formal equality for lesbians and gay men, but the Fourie judgment attempted to accomplish more. The marriage equality legislation eventually passed ${ }^{178}$ could consequently claim greater political legitimacy, and the process of its passage prompted discussion of gay rights issues popularly. In these ways, the Court was able to reinforce the constitutional value of equality in a more productive and potentially enduring manner than if it had merely issued the ruling itself and "read in" language to alter the existing marriage laws. ${ }^{179}$

173. Minister of Home Affairs \& Another v Fourie \& Another 2005 (1) SA 524 (CC) at paras. $148-50$ (S. Afr.).

174. Id. at para. 162 .

175. Id. at para. 158 .

176. Id. at para. 162 .

177. See, e.g., Home Affairs Portfolio Comm., Civil Union Bill, Film \& Publications \& IMMIGRATION AMENDMENT BILls: BRIEFING (Sept. 13, 2006), available at http://www.pmg.org. $\mathrm{za} /$ minutes/20060912-civil-union-bill-films-publications-immigration-amendment-bills-briefingdepartment (discussing "the Fourie judgement [sic] which had placed the Executive, Parliament as well as [the Legal Advisor's] office under considerable pressure to amend the legislation or to alternatively introduce separate legislation ... they also very carefully studied all other Constitutional Court cases and other relevant jurisprudence on the topic of same sex marriages.").

178. Civil Union Act 17 of 2006 (S. Afr.).

179. This was, unsurprisingly, the Court's back-up plan. Fourie 2005 (1) SA at para. 162 ("Should Parliament not correct the defects within this period, Section 30(1) of the Marriage Act 25 of 1961 will forthwith be read as including the words 'or spouse' after the words 'or husband' as 
The Court instead used its exceptional jurisdictional rules and open-ended remedial power to advance substantive equality through a process that bolstered the socio-political elements of equality.

\section{Empowering Private Actors}

The Court's announcement of a constitutional requirement for "meaningful engagement" 180 in Olivia Road also has a potential to support substantive justice in a dramatic way. To best advance the underlying purpose of the social welfare right of access to housing, the Court interpreted it to ensure effective state action to remedy inadequate housing. ${ }^{181}$ Because the Court will require the state to present evidence of good faith consultation with impacted individuals and concerned civil society organizations prior to evictions, affected communities are significantly empowered to advocate for their own rights. Legally permitted but fundamentally unfair state action is unlikely where this process has occurred. Moreover, the results are far more likely to be acceptable to the government and the affected parties and far less likely to be adjudicated before the Court. The Court need not adjudicate all such cases directly because its permissive access provisions allow it to step in to such disputes as necessary.

Furthermore, since the South African Constitution protects a variety of socio-economic rights (in addition to the right to housing that underlies Olivia Road), it seems somewhat likely that the Court will require such consultation (or some analogous process) when the state makes other decisions related to social welfare protections. Such a result would not only lead to improved outcomes for community stakeholders but also increase popular involvement with government-an oft-mentioned goal of Parliament ${ }^{182}$ - and educate the state bureaucracy about ground-level social welfare issues. Even if such a constitutional requirement does not spread to other categories of socio-economic rights, the occurrence of good faith community consultation in one substantive area of social welfare will influence popular expectations in other areas.

\section{Policing the Boundaries of Unjust State Action}

The Court sanctions its role as a capstone court supervising the lower

\footnotetext{
they appear in the marriage formula.").

180. Olivia Road 2008 (3) SA at para. 9.

181. Id. at para. 44.

182. See, e.g., S. AFr. CONST. 1996, ch. 4, $\S \S 59,72$ ("The [NA/NCOP] must . . . facilitate public involvement in the legislative and other processes ....").
} 
judiciary and other brances of government through its generous, purposive interpretation of the Preamble, the Bill of Rights, and the multiple constitutional commands that all state action should serve the justiceoriented values of the Constitution. The Court's broad jurisdiction and access provisions permit the Constitutional Court to ensure that state action does not infringe on traditional rights or permit discrimination by law, i.e., traditional negative liberties adjudication. However, when the procedural authority is paired expansively with social welfare rights or used to require value-based decision-making, it serves substantive justice. The Court does this most notably and effectively in Njongi.

The lesson from the Njongi case is that compliance with legal requirements is an insufficient justification for otherwise unjust administrative action. The obligations to "[i]mprove the quality of life of all citizens and free the potential of each person" 183 as well as to "respect, protect, promote, and fulfil [sic] the rights in the Bill of Rights" 184 create a co-existent requirement on state actors. Those constitutional standards must inform-sometimes decisively-state decision-making. It is unsafe to rely on the assumption that the requisite constitutional standards are incorporated into statutory law sufficiently to protect against "unconscionable" actions. Officials must independently review the impact of their decisions against the values of the Constitution. And the Court seems ready to enforce such expectations; the Njongi judgment clearly implies that the possibility of punitive measures for government officials exists and will be considered by the Court. ${ }^{185}$ Such a threat reinforces the need for serious evaluation of the moral dimension of administrative action, i.e., the impact of constitutional values. It recruits state actors in the direct advancement of substantive justice in their respective areas of responsibility.

\section{E. Reinforcing Fundamental Values.}

One of the Court's most enduring tasks in support of substantive justice is its constant reiteration of the transformative nature of the South African Constitution and of the new values propounded by that Constitution.

We live in a society in which there are great disparities in wealth.

Millions of people are living in deplorable conditions and in great

\footnotetext{
183. Id. pmbl.

184. Id. ch. 2 , sec. 9 .

185. Njongi v Member of the Executive Council, Dep't of Welfare 2008 (4) SA at para. 73 ("In the final analysis there is insufficient basis upon which to make a punitive order against Mr. Kwelita in this case. As I have pointed out above, his affidavit does however reveal much cause for concern.").
} 
poverty.... These conditions already existed when the Constitution was adopted and a commitment to address them, and transform our society into one in which there will be human dignity, freedom and equality, lies at the heart of our new constitutional order. ${ }^{186}$

The Court's frequent reminders of the fundamentally transformative nature of the South African Constitution and the incomplete nature of that transformation serve substantive justice in an indirect but important way. To the extent that the Court's discussion of social welfare rights or of the deeper dimensions of equality and dignity encourages popular or legislative dialogue about constitutional commitments, it further advances the cause of justice reflected in those enumerated rights. This strengthens the role of the Constitution in society, reminding all South Africans that the Constitution's historic promises remain relevant to present problems. It is perhaps a particular role of this first generation of the South African Constitutional Court to reinforce the values of the Constitution's founding generation through its written judgments as much as through its specific judicial orders.

\section{CONCLUSION}

"[T] he procedural and substantive aspects of justice and equity cannot always be separated. The managerial role of the courts may need to find expression in innovative ways." 187

Generous rights interpretation, expansive remedial power, broad jurisdiction, and permissive access rules are the tools of the South African Constitutional Court that allow it to serve the transformative goals of the post-apartheid Constitution. The Court's procedural and interpretive characteristics empower it to serve as the pinnacle institution of a country committed to transformative constitutionalism and substantive justice. The Constitutional Court is, of course, not sufficient for the task of national transformation - no court or judicial system could be- but its willingness to experiment with its authority is a lesson for all courts.

What is already evident is that the recent South African cases discussed in this Article highlight the opportunities for genuine justice and social welfare available to a court that responds creatively to the call for justice and employs all of its tools to build a more just society. The South African Constitutional Court demonstrates an initial collection of such options in the cases discussed in this Article. As the Court uses these tools-in

186. Soobramoney $v$ Minister of Health (Kwazulu-Natal) 1997 (1) SA 765 (CC) at para. 8 (S. Afr.).

187. Port Elizabeth Municipality v Various Occupiers 2005 (1) SA 217 (CC) at para. 39 (S. Afr.). 
conjunction with its extensive textual protections of civil and political and socio-economic rights - it is more empowered than typical national courts but it is also more capable of educating other courts of their capacity to advance substantive justice in their own countries.

Further discussions will have to evaluate whether this expanded capacity to support genuine justice is exclusively the prerogative of the South African courts with their expansive power, but such a conclusion seems very unlikely. The more robust application of its own constitutional values by the South African Constitutional Court is more easily justified by its history and its Constitution, but all constitutions have important, fundamental values. And, at least among courts empowered with judicial review, some application of the fundamental values that undergird the constitution informs all interpretation and application of constitutional rights. The results may be less dramatic in less overtly empowered judicial systems but the South African Constitutional Court can certainly inspire other countries' courts (like it does its own lower courts) to explore their commitment to their own deepest constitutional values and to substantive justice. 